\title{
Interdiszciplinaritás a szoptatás támogatásában
}

\author{
Interdisciplinarity in breastfeeding support
}

\author{
W. Ungváry Renáta ${ }^{1}$, Dr. Bóné Veronika¹, Dr. Kutas Katalin², \\ Juhászné Dr. Kun Judit Gabriella ${ }^{3}$ \\ ${ }^{1}$ Semmelweis Egyetem, EKK Mentálhigiéné Intézet, ${ }^{2}$ Szent Kristóf Szakrendelo, \\ ${ }^{3}$ Szoptatásért Magyar Egyesület
}

A szoptatás egészségre, pszichoszociális fejlődésre gyakorolt pozitív hatásai miatt a szoptatástámogatás a prevenció egyik leghatékonyabb eszköze. Különlegessége abban rejlik, hogy a szoptatás és az anyatejes táplálás jótékony hatása nemcsak a gyermeken, hanem a szoptató édesanyán is hosszútávon, költségeket nem, vagy alig termelve érvényesül. Az egészségügyi ellátórendszeren keresztül megvalósuló szoptatástámogatás minőségének fejlesztése az interdiszciplinaritás jelenleginél kiterjedtebb megvalósulásán, és a humán laktációval kapcsolatos ismeretek megfelelő mélységü oktatásán keresztül lehetséges. Az anya-csecsemő diád ellátásában mindkettőjük szempontjainak érvényesülniük kell. Ha ez nem történik meg, az esetek többségében jelentősen rövidül a szoptatás időtartama és a komorbiditások aránya is nő. Áttekintésünkben bemutatjuk, milyen interdiszciplináris fejlődési lehetőségek állnak a szoptatástámogatásban dolgozók előtt, kitérünk egy új specializáció, a laktációs szaktanácsadó, valamint a szükséges oktatási háttér bemutatására.

The aim of this review is to prove the necessity of interdisciplinarity in breastfeeding support and show evidence explaining the importance of teamwork in support of the breastfeeding dyad. Due to its positive effects on overall health and psychosocial development, breastfeeding support is the most effective method of prevention, as it has lifelong dyadic effect on both the mother and the infant without any additional costs. The exceptionality of breastfeeding is founded in its long term, sufficient and ecologic dyadic impact on both the mother and the infant. For quality improvement of breastfeeding support delivered through the health care system it is necessary to teach appropriate breastfeeding knowledge and improve interdisciplinary teamwork. In health care delivery for the mother-infant dyad there should be enforced interests of both of them. If this is not the case, the shorter the breastfeeding duration is, the higher the prevalence of comorbidities are. In this review possibilities of interdisciplinary teamwork on the field of human lactation are discussed, the new profession of lactation consultants as part of the health care team are introduced and the necessary educational background is also demonstrated.

\section{BEVEZETÉS: \\ A SZOPTATÁSTÁMOGATÁS MINT A PREVENCIÓ LEGHATÉKONYABB ESZKÖZE}

Nincs még egy olyan humán tevékenység, amely a szoptatáshoz hasonlóan jelentős mértékben, rövid és hosszú távú pozitív hatást gyakorolna a populáció egy arányaiban is jelentős szegmensére [1,2]. A XX. században a szoptatási arányok drasztikus csökkenése a fejlett országokban, és ezzel párhuzamosan, a tápszerforgalom globális növekedése olyan negatív népegészségügyi tendenciákat indított el, amelyek 1981-ben az úgynevezett WHO Kódex létrehozását eredményezték. Ez az első olyan nemzetközileg elfogadott dokumentum, amely leszögezi a szoptatás fontosságát, valamint azt, hogy védelemre szorul a tápszermarketinggel szemben [3]. Az 1990-es Innocenti kiáltvány a szoptatásra már a prevenció bizonyítottan leghatékonyabb eszközeként tekint, és sürgeti, hogy a kormányok tegyenek megfelelő lépéseket a szoptatás rendszerszintű védelmében, támogatásában és népszerűsítésében [4]. Több mint 30 évvel az Innocenti deklaráció megjelenése után annak célkitǔzései mindmáig a szoptatástámogatás alapját képezik. Időről időre aktuálissá válik a nemzeti szoptatástámogató stratégiák értékelése hatékonyság szempontjából. Bár a céltudatos intézkedések hatása az esetek többségében a szoptatási arányok növekedésében is megmutatkozik, az egyes intézkedések hatása a szoptatási arányokat befolyásoló tényezők heterogenitása és adatgyűjtési problémák miatt nem mindig egyértelműen megítélhető [5,6].

Számos kutatás igazolta a szoptatás dózisfüggő pozitív hatását a gyermek és az anya egészségére [1,7]. A WHO 2003-ban tette közzé globális ajánlását [8], mely szerint a kizárólagos szoptatás folytatása hat hónapos korig javasolt, majd a szoptatás folytatását ajánlják kétéves korig vagy azon túl a szilárd táplálékok adásával párhuzamosan. Ezt az évek múlásával számos szakmai szervezet tette magáévá csecsemőtáplálási ajánlásában, bár a hosszú távú szoptatás támogatottsága ezekben a dokumentumokban mérsékeltebb [9-12].

Noha a szoptatás minden kétséget kizáróan a biológiai norma, valamint rövid és hosszú távú egészségügyi és pszichés előnyei egyértelműek, sajnos tény, hogy mára a csecsemők többsége világviszonylatban és Magyarországon $[13,14]$ is kevert vagy tápszeres táplálásban részesül, és a szoptatási arányok messze elmaradnak a WHO ajánlásban 
megfogalmazott céloktól. Magyarországon évröl évre növekszik az az összeg, amit a fogyasztók és az egészségbiztosító tápszerre fordít [15]. A szoptatástámogatásnak ezért az egészségpolitika legföbb prioritásai közé kell tartoznia. Számos intézkedés értelme és hatása egyértelmü, ilyen például az egységes csecsemőtáplálási szakmai protokoll [12] nyilvánosságra hozatala, amely az első és legfontosabb lépés annak érdekében, hogy a szoptató anyák az egészségügyi ellátórendszer minden pontján egybehangzó információkat és ellátást kapjanak. További fontos lépés volt a Szoptatást Támogató Nemzeti Bizottság (SZTNB) létrehozása, amely egy interdiszciplináris testület, és mint ilyen, lehetővé teszi, hogy a szoptatástámogatásban dolgozó különféle szakterületek és civil szervezetek képviselői együttmüködhessenek és megismerjék egymás tapasztalatait, álláspontját és munkamódszerét. A bizottság tagjai között gyermekgyógyászok, szülész-nőgyógyászok, védőnők, pszichológusok, csecsemőápolók, szülésznők, laktációs szaktanácsadók, szociológusok, statisztikusok és marketing szakemberek is találhatók. Jelen van a Magyar Védőnők Egyesülete, és a két legfontosabb szoptatástámogató szervezet, a La Leche Liga Magyarország és a Szoptatásért Magyar Egyesület is.

A szoptatás eredetileg a mindennapi élet normális része volt, nem csupán egy lehetséges táplálási mód, hanem olyan multifunkcionális eszköz (életmód), amely a csecsemővel való együttélés számos területén fejthette ki pozitiv hatását. A szoptatás stabilitását, fenntarthatóságát éppen az biztosította, hogy sok lábon állt: megbízható, személyre szabott táplálékot és immunológiai védelmet nyújtott, megnyugtatta a csecsemőt, kielégítette szopási igényét, segítette az elalvást és a megnyugvást, javította a csecsemő közérzetét, csillapította fájdalmát, és mindezen funkciók együttes hatásaként szoros kapcsolatot biztosított az anya és a csecsemő között. A szoptatás azonban az utóbbi 150 évben egyre fokozódó mértékben az egészségügyi ellátórendszer kompetenciakörébe került. Az intézményi szülés elterjedése következtében a szoptatás elkezdése is egészségügyi színtérre került, miközben a hagyományos családi támogatórendszerek generációról generációra gyengültek. A jellegzetes egészségügyi megközelítés és a hagyományos támogató struktúrák felbomlása azonban egyértelműen negatív hatást gyakorolt a szoptatás alakulására, ahogyan azt számos feltáró kutatás bizonyította [16-18.] A negatív hatás egyik fő oka a táplálkozáscentrikus megközelítés, amely hátat fordít a szoptatás komplexitásának. A többi ok az interdiszciplináris megközelítés hiányából, oktatási hiányosságokból és érdekellentétekből fakad. Az egészségügyi ellátás specializálódása miatt nehézségekbe ütközik az anya-csecsemő diád együttes ellátása, és annak figyelembevétele, hogy állapotuk kölcsönösen befolyásolja egymást. A hatékony ellátás érdekében az anya és csecsemő szempontjainak együttesen kellene érvényesülniük. Ha ez nem történik meg, az esetek többségében jelentősen rövidül emiatt a szoptatás időtartama, illetve a komorbiditások aránya nő. Miközben a várandósság alatt evidens a diádikus megközelítés, a szoptatás idején az anya és csecsemő egymásra gyakorolt szinergikus hatása kevésbé tartozik a mindennapos evidenciák körébe, noha egyre több kutatás hívja fel erre a figyelmet [19-21]. A koronavírus pandémia olyan különleges helyzetet teremtett világszerte, amely szükségessé tette a szülészeti, neonatológiai, sürgősségi és területi ellátásban a diádikus szempontok figyelembevételét. Míg az első reakció az elkülönítés volt, a gyakorlatban az anya-csecsemő biológiai egységének és ezáltal a szoptatásnak a fenntartása bizonyult jó stratégiának [20].

Bár a szoptatás időtartamát nem csupán az egészségügyi ellátórendszer nyújtotta teljesítmény befolyásolja, hanem igen nagymértékben a szoptatással kapcsolatos társadalmi és személyes attitúd, az anya-és családvédelmi törvények, a fizetett anyasági szabadság hossza, a dolgozó szoptató anyákat megillető jogok, a szocioökonómiai státusz és még számos más tényező, mégis az egészségügyé a prioritás abból a szempontból, hogy az anyák föként egészségügyi dolgozóktól kapják az információkat és a konkrét segítséget, amikor szoptatási problémáik jelentkeznek. Ez a tény teszi különösen sürgetővé annak tudatosítását, hogy az ellátás optimalizálása csak az interdiszciplinaritás elve mentén képzelhető el.

\section{ELŐZMÉNYEK: INTERDISZCIPLINÁRIS EGÉSZSÉGÜGYI ELLÁTÁS}

Az interdiszciplináris egészségügyi ellátás a 21. század kezdetén vált egyre gyakrabban használt fogalommá. $A z$ egészségügyi ellátás színvonalának növelésében mind fontosabb tényezővé vált a különböző szakterületek együttmüködése az ellátott problémák komplexitása miatt és a jobb kimenetel érdekében. Az Institute of Medicine egészségügyi dolgozók oktatásával foglalkozó munkacsoportja adta ki az első kézikönyvet [22] (Bridge to Quality) arról, melyek az interdiszciplináris együttmüködés legfontosabb kompetenciái, és ezek milyen formában oktathatók. Az ellátás minőségi javulásának kulcsa a kézikönyv szerint a páciensközpontú ellátás, az interdiszciplináris csapat, a bizonyítékokra alapozott gyógyítás, a minőségbiztosító rendszer és a megfeleló informatikai háttér. Fontos tényező a folyamatok átláthatósága, a kutatási súlypontok kijelölése és az eredmények bemutatása a közvéleménynek.

A WHO gyakorlati kézikönyvet állított össze az interdiszciplináris együttműködés elösegítésére [23]. A hagyományos, hierarchikus ellátás a kezelésre összpontosít, szemben a páciensközpontú ellátással, amely az egészségügyi ellátók csapatmunkájára és a páciens döntéshozatalba történő bevonására épít. A specializálódás fokozódása, részismeretek gazdagodása még inkább előtérbe helyezte a szakterületek közötti együttműködés szükségességét, és ennek érdekében az interdiszciplináris és a páciens felé irányuló kommunikációs stratégiák fejlesztését is.

A kommunikációs stílus alapján többféle döntéshozatali modellt különböztethetünk meg. Ezek közül az ún. „közös döntés" (a nemzetközi szakirodalomban shared decision making, SDM) az, amely az interdiszciplinaritás témájához 
legjobban illeszkedik, és amely egyre nagyobb támogatottságot élvez az egészségügyi ellátórendszerekben. A közös döntés koncepciója az 1990-es években jelent meg a szakirodalomban, amelynek legfontosabb jellemzői: a döntésben legalább két személy - a szakember (orvos) és a páciens vesz részt; kölcsönösen megosztják az információkat; mindketten lépéseket tesznek a konszenzus érdekében, majd pedig megegyeznek a döntésben [24]. Az SDM nem egységes modell, számos fajtája létezik, és a mai napig vita folyik arról, hogy valójában mit is foglal magában. Egyértelmú azonban, hogy a megfelelő kommunikáció nélkülözhetetlen része a folyamatnak [25].

Noha Magyarországon is egyre erőteljesebben hallatják hangjukat azok, akik a páciensközpontú ellátás részeként igényelnék a közös döntéshozatalt, a hazánkban néhány éve elvégzett kutatások azt igazolják, hogy a társadalom nagy része elfogadja a szakember irányítását az egészségét érintő kérdésekben. Bár ez a szereposztás látszólag mindkét fél számára kényelmes, számos buktatót hordoz magában, hiszen a döntés felelősségét a szakember, a döntés következményeit pedig a páciens hordozza, lévén az ő testéről van szó. A szerzők megállapítása szerint a közös döntéshozatalt az esetek többségében az elégtelen kommunikáció akadályozza [26]. Mindez a szoptatástámogatás területén különösen nagy jelentőséggel bír a szoptatási hajlandóságot befolyásoló számos tényező miatt, hiszen döntően az egészségügyi ellátórendszerből származó lépésekkel e tényezők számottevő része nem befolyásolható.

\section{A LAKTÁCIÓS SZAKTANÁCSADÓ} MINT AZ INTERDISZCIPLINÁRIS TEAM TAGJA

Az egészségügyön belül zajló specializálódás új szakterületek és foglalkozások megjelenését eredményezte, ilyen például a laktációs szaktanácsadó, aki korábban több munkaterülethez (szülész-nőgyógyász, gyermekorvos, szülésznő, védőnő, csecsemőápoló, dietetikus, pszichológus, pszichiáter) tartozó részfeladatok új specialistája lett.

A szoptatási tanácsadás mint szakma megjelenésének szükségessége a 80-as évekre vált nyilvánvalóvá. Az 1956ban alapított La Leche Liga tevékenysége indította el, amely szervezet eleinte sorstárs segítőcsoportok létrehozásával támogatta az anyákat, később úttörője volt a szoptatás tudományos megalapozásának, illetve a szoptatási tanácsadás önálló szakmaként való elismerésének. A kezdetektől együttműködtek az egészségügyi dolgozókkal, facilitálták a szoptatás tudományos hátterének minél alaposabb feltárását, majd részt vettek a szoptatási tanácsadás szakmai sztenderdjeinek kidolgozásában. A különböző szakemberek együttmüködésének köszönhetően 1985-ben létrejött a Laktációs Szaktanácsadók Nemzetközi Vizsgabizottsága, (International Board of Lactation Consultant Examiners IBLCE) amely jelenleg is világszerte több helyszínen és több nyelven biztosítja a laktációs szaktanácsadó (International Board Certified Lactation Consultants - IBCLC) végzettség megszerzésének lehetőségét [27]. A később (2008) felállított
Laktációs Képzések Akkreditációjáért, Jóváhagyásáért Felelős Bizottság (Lactation Education Accreditation and Approval Review Committee, LEAARC) feladata lett a világszerte elérhető laktációs oktatási programok értékelése aszerint, hogy megfelelnek-e a felállított sztenderdeknek, de a vizsga teljesítése továbbra is bárki számára elérhető [28].

A szoptatási tanácsadás - bár döntően egészségügyi szakemberek végzik - soha nem volt kizárólag az egészségügy felségterülete. Az IBCLC-cím kezdetektől megszerezhető volt nem egészségügyi végzettséggel, az IBLCE külön teljesítési útvonalat biztosít a társszakmák képviselői számára, felismerve, hogy maga az anyákkal, társadalommal végzett munka csak interdiszciplináris megközelítésben lehet teljes. „Egészségügyi társszakmaként” a tanácsadók mindig az egészségügyi rendszer részeként dolgoznak, de működésük kontextusa nagyon széles spektrumon mozog a speciális klinikai környezettől az attól teljesen független otthoni-társadalmi környezetig [29]. Ehhez illeszkedően az IBLCE által szervezett minősítővizsga tartalmaz antropológiai, pszichológiai, szociológiai és társadalomtudományi kutatásmódszertani elemeket is, amelyről többet az IBLCE honlapjáról lehet megtudni (www.iblce.org). A humán laktációs ismeretanyagot összefoglaló, legfrissebb kézikönyv (Core curriculum for Interdisciplinary Lactation Care) már szemléletében és tartalmában is a különböző szakterületek együttmüködésére és speciális szempontjaira alapoz [30].

\section{SZAKEMBEREK A SZOPTATÁSTÁMOGATÁSBAN MAGYARORSZÁGON}

Ma már Magyarországon is megtalálhatóak a kifejezetten a szoptatás támogatására képzett szakemberek és segítők. Az önkéntes szoptatási segítők olyan, általában saját szoptatási tapasztalattal rendelkező nők, akik elsősorban a szűkebb környezetükben, rokoni vagy baráti körükben segítik a szoptatni kívánó anyákat. Kompetenciájuk a szoptatás alapvető elméleti és gyakorlati ismereteinek átadására, a gyakori problémák megelőzésére, az anya támogatására, illetve a képzettebb szakembert igénylő esetek felismerésére terjed ki. A Szoptatásért Magyar Egyesület önkéntes képzése 80 órás, amely az elméleti és gyakorlati ismereteken túl nagy hangsúlyt fektet a jelöltek önismeretére és élményfeldolgozására, továbbá a kompetenciahatárok kijelölésére. Van ennél jóval rövidebb, 16 órás e-learning rendszerű képzés is. Kétségkívül aggodalomra okot adó tendencia, hogy az azonos megnevezés mögött jelentősen eltérő felkészültségú segítőkkel találkozhat a kliens.

A La Leche Liga (LLL) szoptatási tanácsadók a Nemzetközi La Leche Liga által akkreditált, saját szoptatási tapasztalattal is rendelkező, alaposan képzett személyek, akik elsősorban anyacsoportokban, továbbá telefonos és e-mailes tanácsadás formájában segítik a hozzájuk fordulókat. A nemzetközi szervezet nagy hangsúlyt fektet már a jelöltek kiválasztására is: a képzésbe csak olyan személy léphet be, aki az LLL csoportok látogatása révén behatóan megismerte az LLL szemléletét, személyisége és kommunikációja befogadó, 
támogató, ítélkezéstől mentes. A több hónapig tartó képzés során a jelölt mélyreható felkészítést kap a laktáció és szoptatástámogatás elméleti és gyakorlati témáin túl a telefonos tanácsadás, csoportszervezés, -vezetés és -dinamika kérdéseiről is. Mind az önkéntes szoptatási segítők, mind az LLL szoptatási tanácsadók önkéntes alapon, térítésmentesen végzik szolgáltatásukat. Mivel előrejelzések szerint 2030-ra már világszerte 18 millió egészségügyi dolgozó fog hiányozni az ellátórendszerből [31,32], kiemelt jelentősége van annak, hogy a szoptatástámogatásban - akár egészségügyi intézményekben is - szerepet kapjanak a jól képzett, kompetenciahatáraikat ismerő önkéntes segítők, másfelől az ellátás decentralizálódjon, és új útvonalakat találjon például a telemedicina és a közösségi támogatás felhasználásával.

Az IBCLC laktációs szaktanácsadó a humán laktáció és szoptatástámogatás területén magasan képzett szakember. Feladata elsősorban azokra az esetekre irányul, ahol az anya-csecsemő páros komplex ellátásához szükség van speciális szaktudására. A Nemzetközi Vizsgabizottság meghatározott egészségügyi alapismereteket (vagy egészségügyi végzettséget), 1000 óra önálló vagy 500 óra mentorált szoptatási tanácsadói gyakorlatot és legalább 90 óra elméleti képzést ír elő bemeneti követelményként a jelöltek részére. $A$ sikeres vizsgát követően kiadott oklevél öt évig érvényes, amely megfelelő továbbképzési pontok gyűjtésével újabb öt évre meghosszabbítható. Az IBCLC cím megtartásához tíz évente ismételten le kell tenni a nemzetközi vizsgát.

\section{INTERDISZCIPLINÁRIS OKTATÁS A SZOPTATÁSTÁMOGATÁS TERÜLETÉN}

Speciális sajátosság, hogy egy új tudományterület vagy új szakma fejlődésekor nem a képzést hozzák létre elsőként, hanem a vizsgarendszert dolgozzák ki. Ez azt is jelenti, hogy bár a képesítés megszerzéséhez szükséges tudás a részletes vizsgaleírásnak köszönhetően egységes, az oda vezető út, a képzési formák meglehetősen heterogének. Bár továbbra sem feltétele a vizsga letételének a diploma, azonban a felsőoktatásban végzett különböző témájú kurzusok igazolása egyre növekvő mértékben feltétel [33]. Mind a vizsga bemeneti feltételeként megszabott alapozó tárgyak, mind a különböző szintű laktáció specifikus kurzusok, kurzuscsoportok, képzések közös vonása az interdiszciplinaritás, akár egészségügyi dolgozók alapismeretének növelése a cél, akár felkészítés az IBCLC minősítésre [34].

Magyarországon az ezredfordulón jelentek meg a minősített laktációs szaktanácsadók. Ezt követően évről évre egyre többen szereztek laktációs szaktanácsadó címet, ma már jóval száz feletti laktációs tanácsadói létszámmal rendelkezünk. Ebben nagy szerepe volt a Semmelweis Egyetemen 2010-ben indított laktációs szaktanácsadó szakirányú továbbképzésnek. A képzés szakanyagában illeszkedik a nemzetközi sztenderdekhez, továbbá biztosítja mind oktatói összetételében, mind tematikájában, mind a hallgatói heterogenitásban az interdiszciplinaritást, azaz elvégzése nyitva áll a nem egészségügyi végzettséggel rendelkezők számára, és különféle egészségügyi szakterületek és szintek képviselői számára is [35]. A képzés eddigi 11 évfolyamának hallgatói között orvosok, szülésznők, gyógyszerészek, védőnők, csecsemőápolók, tanárok, biológusok, pszichológusok és szociológusok is voltak. A Semmelweis Egyetem Laktációs Szaktanácsadó Szakirányú Továbbképzési Szakán végzett laktációs szaktanácsadók az IBCLC laktációs szaktanácsadókhoz hasonlóan magasan képzett szakemberek. A képzés az orvos- és egészségtudomány, bölcsészettudomány, társadalomtudomány, illetve pedagógusképzés képzési területén megszerzett diplomára épül. Bemeneti követelményei között szintén szerepelnek az egészségügyi alapismeretek és a szoptatási tanácsadói gyakorlat. A másfél éves képzés során átadott ismeretek a hallgatókat felkészítik a nemzetközi vizsgára is, így sokan közülük a magyar oklevélen túl a nemzetközi végzettséget is megszerzik.

\section{JELLEGZETES KIHÍVÁSOK A SZOPTATÁSTÁMOGATÁS TERÜLETÉN}

A szoptatástámogatás interdiszciplináris folyamat. A perinatális időszakban a várandós és kisgyermekes anya és családja számos egészségügyi és más segítő szakemberrel találkozik, akiknek az elméleti ismeretei, gyakorlati készségei, attitüdje és kommunikációja jelentős hatással lehetnek a szoptatás sikerére.

A szülészorvos, a szülésznő, a gyermekorvos, a védőnő és a csecsemőápoló az ellátó teamben betöltött szerepének megfelelően különböző mennyiségű információt ad át a szoptatásról pácienseinek. Minden, a perinatális időszakban anyákkal és családokkal foglalkozó szakembernek egységesen korszerű elméleti és gyakorlati ismeretekkel kell rendelkeznie a szoptatásról és a segítő kommunikációról. Amint az Henshaw és munkatársai kutatásából [36] kiderül, a szülés körüli időszakban a szülőknek a legnagyobb nehézséget a kapott információk ellentmondásossága okozta. McAndrew és munkatársai kutatása szerint a szoptatást abbahagyó nők 80 százaléka szívesen folytatta volna a szoptatást, ha megfelelő támogatást kap [37]. Megdöbbentő adat, hogy egy Egyesült Államokbeli interdiszciplináris szoptatási klinikát felkereső páciensek korábban már átlagosan 7,7 segítőt kerestek fel - hiába, mert problémájuk nem oldódott meg. A sikeres segítségnyújtás alapja a megerősítés és a specifikus információ volt [38].

A szoptatásra való felkészítésben részt vesz a védőnő, a szülésznő, gyakran a laktációs szaktanácsadó és a szülészorvos is. A szülőszobai szoptatásnál a szülésznő segédkezik, az osztályon a csecsemőápoló, kórházi védőnő. Problémák esetén szoptatásban járatos szakembert, laktációs szaktanácsadót célszerű bevonni az ellátásba. Mannel és munkatársai javaslatot tesznek a sürgősségi szintnek megfelelő ellátásra a diádikus szempontok és a szóba jövő nehézségek osztályozása segítségével [39]. Amennyiben a tejátvitel nem elégséges, a neonatológus állapítja meg a pótlás szükségességét és a mértékét. A szoptatásbarát pótlási technikát és a 
mell kiürítésének mikéntjét a csecsemőápoló vagy a laktációs tanácsadó tanítja meg az anyának. Hazaérkezés után a védőnő 48 órán belül a család otthonába látogatva segít a megfelelő szoptatási gyakorlat kialakításában, a baba állapotát, gyarapodását a háziorvossal, házi gyermekorvossal együtt követi - lehetőség szerint összhangban a szülészeti intézményben kapott javaslatokkal. Amennyiben a szoptatási probléma nem oldódott meg a kórházban, vagy otthon alakult ki, a legjobb kimenetel érdekében a szülő-védőnőlaktációs tanácsadó-gyermekorvos együttműködésére van szükség, melynek egyik alapvető feltétele a megfelelő dokumentáció.

\section{PÉLDÁK AZ INTERDISZCIPLINARITÁS SZÜKSÉGESSÉGÉRE A SZOPTATÁSTÁMOGATÁSBAN}

A társszakmák együttműködése jelentős előnnyel jár a következő esetekben is:

Anyai metabolikus zavar: Magyarországon a szülőképes korú nők 40\%-a túlsúlyos vagy elhízott, és a helyzet romlik. Következményeként kialakulhat inzulinrezisztencia, terhességi diabetes, vérnyomás-emelkedés, gyakoribbak a szülészeti komplikációk. A magzatnál létrejövő szívfejlődési rendellenesség, makroszómia hosszútávú egészségkárosodással járhat, az első napokban pedig az újszülöttnél gyakoribb az alacsony vércukor, a sárgaság kialakulása - amely problémák a szoptatás megalapozásának fázisában jelentenek nehézséget. Optimális esetben a prénatalis gondozás, komplex életmódváltó program javulást hozhat mindkettőjük metabolikus állapotában, dietetikus, gyógytornász és egészségpszichológus bevonásával [40]. A szoptatás az anyánál és a csecsemőnél is a diabetes ellen hat [41], támogatja a fogyást, csökkenti a gyermek esélyét az elhízásra. Az anyai metabolikus zavar hormonális úton késlelteti a tejbelövellést, az elhízás és a gyakoribb császármetszés technikailag nehezíti a szoptatást [42], ezért már a szülés előtt érdemes felkészülni a várható kihívásokra. Szülés után pedig proaktív teammunka javasolt: korai mellrehelyezés a szülésznő segítségével, technikai segítség a mellretételnél a nagyobb mell, mellbimbó miatt laktációs szakember részéről, az újszülött metabolikus állapotát, a pótlás szükségességét, mennyiségét pedig a gyermekorvos követi. Az első hetek nehézségei után a teljes szoptatás jó eséllyel elérhető. $A$ „Három generációval az egészségért program" [43] jó hátteret nyújtott az életmódváltás elkezdéséhez.

Pszichés gátak: A szoptatás erősíti az anya és az újszülött kötődését, támogatja az anyai kompetenciaérzést, csökkenti a szülés utáni depresszió előfordulását [44], enyhítheti a szorongásos tüneteket - bár az ok-okozati összefüggések feltárása még várat magára [45,46]. Amennyiben az anyacsecsemő diád egymásra hangolódása pszichés problémák következtében sikertelen, funkcionális problémák, táplálási, emésztési, alvási gondok léphetnek fel a csecsemőnél, mely esetekben első lépésként védőnő, laktációs szaktanácsadó és integrált szülő-csecsemő konzulens bevonása és együtt- működése segíthet. A Szent János Kórház Baba-mamapapa programja kórházi pszichiátriai ellátást igénylő édesanyák és csecsemőjük számára nyújt interdiszciplináris, diádikus szempontokat figyelembe vevő ellátást, a szülészet, az újszülöttosztály és a pszichiátria (ezen belül laktációs szaktanácsadó orvos) együttműködésével. Az ellátás alapelveit összefoglaló szakmai irányelv [47] ugyanakkor megállapítja, hogy a posztpartum depresszió, posztpartum stressz-zavar, posztpartum pszichózis és más mentális betegségek előfordulása esetén az ellátásra Magyarországon az esetlegesség jellemző, a különböző szakterületek (gyermekjólét, családsegítő, szociális munkás, védőnő) együttműködése sporadikus, a szülői hivatásra felkészítő programoknak pedig általában nem része a pszichés zavarokkal kapcsolatos információátadás. Szorongásos, depresszív tünetek, a magzathoz való kötődés zavara esetén pszichológus bevonása lehet szükséges, Csongrád megyében pl. védőnői szűrést követően ajánlanak fel pszichológiai konzultációt, gasztroenterológusi, fejlődésneurológusi háttérrel. Az interdiszciplináris megközelítésre jó példa a Heim Pál Kórház Koragyermekkori evés-alvás ambulanciája, melynek munkatársai között gyermekgyógyász, pszichológus, gyermekpszichiáter, csecsemőápoló, logopédus, integrált szülő-csecsemő konzulens és laktációs szaktanácsadó orvos is van [48]

Koraszülöttség: Az újszülöttek 9 százaléka koraszülött. Az ő esetükben a szoptatás, az anyatejes táplálás életmentő, többek között a necrotizáló enterocolitis esélyét az anyatej csökkenti a leghatékonyabban [49-51]. Ugyanakkor kezdetben a szoptatásra sem az anyai, sem az újszülött szervezete nem áll készen, és a tejelválasztás felépítése időablakos: a fejés korai elkezdése, progresszív emelése döntő jelentőségű. Ha az újszülöttet másik intézménybe szállítják, a szülésznő, a szülészorvos és az ápolók szoptatástámogató hozzáállása különösen fontos és nélkülözhetetlen. A kengurugondozás, a szülő bevonása a gyermek ápolásába, és a szoptatás megkezdése az újszülöttápoló és a laktációs tanácsadó szoros együttműködését, és a neonatológus támogatását, felügyeletét igényli. A Melletted a helyem Egyesület az intézményi interdiszcipináris ellátás támogatására jó példa, a Dél-Alföldön a Koramentorház Program a közösségi, holisztikus komplex ellátást igyekszik megvalósítani.

\section{ÖSSZEGZÉS, KÖVETKEZTETÉSEK}

T. Király és munkatársai vizsgálták, hogyan lehetne javítani az orvos-laktációs szaktanácsadó kommunikáción. Kutatásukból kiderült, hogy az anya-csecsemő diád ellátásában érintett orvosok jelentős része nem is tud a laktációs szaktanácsadók létezéséről, sem azokról a képzésekről, ahol a humán laktációval kapcsolatos ismereteiket bővíthetnék. Mint az eredményeikből kiderül, az együttműködést különösen hatékonnyá tette a valamennyi fél számára érthető és hozzáférhető dokumentáció [52]. Következtetéseik hazai 
viszonylatban is hasznosíthatóak: van hová fejlődnünk dokumentálás terén, a laktációs szaktanácsadó szakma és a szoptatástámogatásra oktató képzési lehetőségek ismertté tételében, illetve ezek integrálásában az egészségügyi dolgozók és az orvosok képzésébe. Ennek érdekében a Családbarát Szülészetek program keretében több száz egészségügyi dolgozó humán laktációval kapcsolatos, tápszercégektől független oktatására került sor az elmúlt év folyamán. Különösen jelentős elörelépés, hogy ezek az oktatások érdekellentétektől mentesen [53], állami finanszírozással kerültek megvalósításra.
A megvalósítandó célok közé tartozik még, hogy az újonnan készülő, illetve megújuló, anya-csecsemő ellátást érintő szakmai irányelvek elkészítésébe, véleményezésébe laktációs szaktanácsadókat is bevonjanak, illetve szülészeti intézményekben és a védőnői, területi ellátásban is a minimumkövetelmények közé kerüljön a laktációs szaktanácsadó alkalmazása, illetve ennek a kiegészítő végzettségnek a megszerzése. Mindezek megvalósulása végső soron az anya-csecsemő diád hatékonyabb támogatását, a szoptatás gyakoribbá válását és hosszabb távú fenntartását teszi majd lehetővé.

\section{IRODALOMJEGYZÉK}

[1] Victora CG, Bahl R, Barros AJ et al.: Breastfeeding in the 21st century: epidemiology, mechanisms, and lifelong effect. The Lancet. 2016; 387: 475-490. https://doi.org/10.1016/S0140-6736(15)01024-7

[2] Geddes DT: Discard the Stereotype, Strengthen the Science, and Experience Success. Journal of Human Lactation. 2013; 29: 122-122. https://doi.org/10.1177/0890334413477918

[3] WHO: International Code of Marketing of Breast-milk Substitutes. In: World Health Organization (ed). Geneva, 1981

[4] Innocenti Declaration. Breastfeeding in the 1990s: A Global Initiative. Florence, Italy, 1990.

[5] Bóné V, Ungváry R, Juhászné-Kun J, Kutas $K$, Gitidiszné Gyetván K, Gárdos L: Lessons learnt from the national and international breastfeeding strategies. Journal of Hungarian Interdisciplinary Medicine. 2021; 20: 39-44. https://doi.org/10.53020/IME-2021-106

[6] Gupta A, Suri, Shoba JP, Dadhich et al.: The World Breastfeeding Trends Initiative: Implementation of the Global Strategy for Infant and Young Child Feeding in 84 countries. Journal of Public Health Policy. 2019; 40: 35-65. https://doi.org/10.1057/s41271-018-0153-9

[7] Kramer MS, Kakuma R: Optimal duration of exclusive breastfeeding. Cochrane Database of Systematic Reviews. 2012; https://doi.org/10.1002/14651858.CD003517.pub2

[8] Global strategy for infant and young child feeding. World Health Organization, Geneva, 2003.

[9] Breastfeeding, Section One: Breastfeeding and the Use of Human Milk. Pediatrics. 2012; 129: e827-e841. https://doi.org/10.1542/peds.2011-3552

[10] Breastfeeding and Lactation for Medical Trainees. Available from: < https://www.aafp.org/about/policies/ all/breastfeeding-lactation-medical-trainees.html > (Megtekintve: 22 08, 2020)

[11] Fewtrell M, Bronsky J, Campoy C et al.: Complementary Feeding: A Position Paper by the European Society for Paediatric Gastroenterology, Hepatology, and Nutrition
(ESPGHAN) Committee on Nutrition. J Pediatr Gastroenterol Nutr. 2017; 64: 119-132. https://doi.org/10.1097/MPG.0000000000001454

[12] Az Emberi Erőforrások Minisztériuma szakmai irányelve az egészséges csecsemő (0-12 hónapos) táplálásáról. 2019. http://www.hbcs.hu/uploads/jogszabaly/2981/fajlok/EMMI_szakmai_iranyelve_\%20csecsemo.pdf (Megtekintve: 07. 07. 2020)

[13] In: Védőnői tevékenység adatai (ed). Gyermek-Alapellátási információs portál, 2019 http://www.gyermekalapellatas.hu/felmeresek/vedonoi_adatok (Megtekintve: 20. 07. 2020)

[14] A csecsemők táplálása [Infant feeding]. Available from: $<$ https://www.kohorsz18.hu/eredmenyek/elozetes-eredmenyek/49-csecsemok-taplalasa.html> (Megtekintve: $0707,2020)$.

[15] Csecsemőtáplálási és tápszerforgalmi adatok Magyarországon [Infant feeding data and Formula Trade in Hungary]. Available from: <http://szoptatas.info/csecsemotaplalasi_es_tapszerforgalmi_adatok> (Megtekintve: 07. 07. 2020).

[16] Apple RD: The medicalization of infant feeding in the United States and New Zealand: two countries, one experience. J Hum Lact. 1994; 10: 31-37. https://doi.org/10.1177/089033449401000125.

[17] Spieler L: American Indians and Alaska Natives: breastfeeding disparities and resources. Breastfeeding medicine : the official journal of the Academy of Breastfeeding Medicine. 2010; 5: 219-220. [eng] https://doi.org/10.1089/bfm.2010.0039

[18] Mclsaac KE, Sellen DW, Lou W et al.: Prevalence and Characteristics Associated with Breastfeeding Initiation Among Canadian Inuit from the 2007-2008 Nunavut Inuit Child Health Survey. Matern Child Health J. 2015; 19: 2003-2011. https://doi.org/10.1177/0890334413515752

[19] Bertrando S, Vajro P: NAFLD at the Interface of the Mother-Infant Dyad. Curr Pharm Des. 2020; 26: 1119-1125. https://doi.org/10.2174/1381612826666200122153055 
[20] Lubbe W, Botha E, Niela-Vilen $\mathrm{H}$ et al.: Breastfeeding during the COVID-19 pandemic - a literature review for clinical practice. Int Breastfeed J. 2020; 15: 82. https://doi.org/10.1186/s13006-020-00319-3

[21] Marinelli KA, Ball HL, Mckenna JJ et al.: An Integrated Analysis of Maternal-Infant Sleep, Breastfeeding, and Sudden Infant Death Syndrome Research Supporting a Balanced Discourse. J Hum Lact. 2019; 35: 510-520. https://doi.org/10.1177/0890334419851797

[22] Institute of Medicine Committee on the Health Professions Education, In: Greiner AC, Knebel E. (szerk.) Translated Health Professions Education: A Bridge to Quality.] National Academies Press (US) Washington (DC). 2003, pp.

[23] WHO: Framework for action on interprofessional education and collaborative practice. Geneva: World Health Organization, 2010

[24] Charles C, Gafni A, Whelan T: Shared decision-making in the medical encounter: what does it mean? (or it takes at least two to tango). Soc Sci Med. 1997; 44: 681-692. https://doi.org/10.1016/S0277-9536(96)00221-3

[25] Bomhof-Roordink H, Gärtner FR, Stiggelbout AM et al.: Key components of shared decision making models: a systematic review. BMJ Open. 2019; 9: e031763. https://doi.org/10.1136/bmjopen-2019-031763

[26] Málovics É, Vajda B, Kuba P: Paternalizmus vagy közös döntés? Páciensek az orvos - beteg kommunikációról. In: E Hetesi, Z Majó, M Lukovics. (ed.) A szolgáltatások világa. In: E Hetesi, Z Majó, M Lukovics. (szerk.) Translated A szolgáltatások világa.] JATEPress, Szeged. 2009, pp. 250-264.

[27] Wambach K, Riordan J: Szoptatás és humán laktáció Semmelweis Kiadó, 2019.

[28] Webber E, Watkins AL: Evolution of a profession: The role of accreditation in lactation education. Journal of Human Lactation. 2017; 33 (4): 740-744. https://doi.org/10.1177/0890334417711893

[29] Eden AR: The professionalization and practice of lactation consulting: medicalized knowledge, humanistic careUniversity of South Florida, 2013. Dissertation. https://digitalcommons.usf.edu/cgi/viewcontent.cgi?articl e=5674\&context=etd (Megtekintve 21 . 08. 2020]

[30] Campbell Sh, Lauwers J, Mannel R, Spencer B: Core Curriculum for Interdisciplinary Lactation CareJones \& Bartlett Learning, 2019.

[31] Darzi A, Evans T: The global shortage of health workersan opportunity to transform care. Lancet. 2016; 388: 2576-2577. [eng] https://doi.org/10.1016/S0140-6736(16)32235-8

[32] WHO: Health workforce and services. Draft global strategy on human resources for health: workforce 2030. In: World health Assembly (ed), 2016

[33] Thomas EV.: "You know if you quit, that's failure, right?": Barriers to professional lactation certification. Journal of Human Lactation. 2018; 34: 454-466. https://doi.org/10.1177/0890334418775062
[34] Howett, M, Spangler, A, Cannon, R B.: Designing a university-based lactation course. Journal of Human Lactation. 2006; 22: 104-107. https://doi.org/10.1177/0890334405283668

[35] Bóné V, Török Sz: Specific Features and Novelty of the Hungarian Lactation Consultant Post Graduate Course. In: János Tibor Karlovitz. (ed.) Questions and Perspectives in Education. In: János Tibor Karlovitz. (szerk.) Translated Questions and Perspectives in Education.] International Research Institute, Komárno. 2013, pp. 7.

[36] Henshaw EJ, Cooper MA, Jaramillo M et al.: "Trying to Figure Out If You're Doing Things Right, and Where to Get the Info": Parents Recall Information and Support Needed During the First 6 weeks Postpartum. Maternal and Child Health Journal. 2018; 22: 1668-1675. https://doi.org/10.1007/s10995-018-2565-3

[37] Health and Social Care Information Centre, Iff Research: Infant Feeding Survey 2010. In: Thompson J, McAndrew F, Fellows L, Large A, Speed M and Renfrew MJ (eds): Health and Social Care Information Centre, 20 November 2012

[38] Miller AS, Telford ACJ, Huizinga B et al.: What Breastfeeding Mothers Want Specific Contextualized Help. Clinical Lactation. 2015; 6: 117-123.

DOI: 10.1891/2158-0782.6.3.117

[39] Mannel R.: Defining Lactation Acuity to Improve Patient Safety and Outcomes. Journal of Human Lactation. 2011; 27: 163-170. https://doi.org/10.1177/0890334410397198

[40] ACOG Committee opinion no. 549: obesity in pregnancy. Obstet Gynecol. 2013; 121: 213-217. [eng] https://doi.org/10.1007/s10995-018-2565-3

[41] Chowdhury R, Sinha B, Sanka MJ et al.: Breastfeeding and maternal health outcomes: a systematic review and meta-analysis. Acta Paediatr. 2015; 104: 96-113. https://doi.org/10.1111/apa.13102

[42] O'Sullivan EJ, Perrine CG, Rasmussen KM.: Early Breastfeeding Problems Mediate the Negative Association between Maternal Obesity and Exclusive Breastfeeding at 1 and 2 Months Postpartum. The Journal of nutrition. 2015; 145: 2369-2378. https://doi.org/10.3945/jn.115.214619

[43] Országos Kórházi Főigazgatóság,: Három generációval az egészségért program - Three generations for health framework. 2020. https://okfo.gov.hu/3g-program (Megtekintve 10.07.2020]

[44] Shimao M, Matsumura K, Tsuchida A et al.: Influence of infants' feeding patterns and duration on mothers' postpartum depression: A nationwide birth cohort-The Japan Environment and Children's Study (JECS). Journal of Affective Disorders. 2021; 285: 152-159. https://doi.org/10.1016/j.jad.2021.02.011

[45] Dias CC, Figueiredo B: Breastfeeding and depression: a systematic review of the literature. J Affect Disord. 2015; 171: 142-154. [eng] https://doi.org/10.1016/j.jad.2014.09.022 
[46] Gunst A, Sundén M, Korja R et al.: Postpartum depression and mother-offspring conflict over maternal investment. Evolution, Medicine, and Public Health. 2021; 9: 11-23. https://doi.org/10.1093/emph/eoaa049

[47] Kurimay T et al.: Az Emberi Erőforrások Minisztériuma szakmai irányelve a pre-, peri- és posztnatális mentális zavarok baba-mama-papa egységében történő kezeléséről. In: EMMI (ed). Hungary, Budapest, 2017 https://www.hbcs.hu/uploads/jogszabaly/2485/fajlok/EE MI_szakmai_iranyelve_a_pre_peri.pdf (Megtekintve 15 . 07. 2020)

[48] Heim Pál Kórház Koragyermekkori evés-alvás ambulancia. Available from: <http://heimpalkorhaz.hu/blog/rendelo/koragyermekkori-eves-alvaszavar-ambulancia/> (Megtekintve: 07. 07. 2020)

[49] Cacho NT, Parker LA, Neu J: Necrotizing Enterocolitis and Human Milk Feeding: A Systematic Review. Clin Perinatol. 2017; 44: 49-67.

https://doi.org/10.1016/j.clp.2016.11.009
[50] Patel AL, Kim JH: Human milk and necrotizing enterocolitis. Semin Pediatr Surg. 2018; 27: 34-38. https://doi.org/10.1053/j.sempedsurg.2017.11.007

[51] Miller J, Tonkin E, Damarell RA et al.: A Systematic Review and Meta-Analysis of Human Milk Feeding and Morbidity in Very Low Birth Weight Infants. Nutrients. 2018; 10: https://doi.org/10.3390/nu10060707

[52] Kiraly T, Quinn S, Fyfe J et al.: Walk the Doc Talk Improving Interpersonal Communication and Collaboration Between Doctors and Lactation Consultants. Clinical Lactation. 2016; 7: 49-56. https://doi.org/10.1891/2158-0782.7.2.49

[53] Lhotska L, Richter J, Arendt M: Lactation Newsmakers: Protecting Breastfeeding From Conflicts of Interest. Journal of Human Lactation. 2020; 36: 22-28. https://doi.org/10.1177/0890334419885859

\section{A SZERZÖK BEMUTATÁSA}

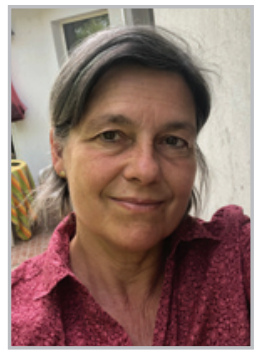

W. Ungváry Renáta 2001-től La Leche Liga szoptatási tanácsadó, 2003-tól nemzetközi vizsgával rendelkező laktációs szaktanácsadó (IBCLC) A Szoptatást Támogató Nemzeti Bizottság tagja, a Semmelweis Egyetem laktációs szaktanácsadó szakirányú továbbképzésének ügyvivő szakértője.

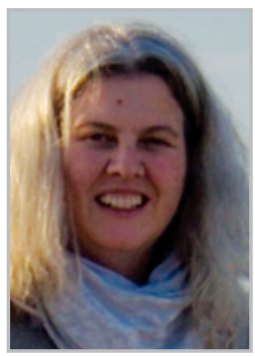

Dr. Kutas Katalin csecsemő- és gyermekgyógyász, IBCLC laktációs szaktanácsadó. 2012 óta dolgozik házi gyermekorvosként, tagja a Biztos Kezek Alapellátó Gyermekorvosok Tudományos Társaságának, a megalakult SZTNB Bababarát terület munkacsoportjának vezetője.

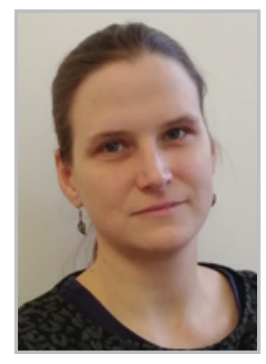

Dr. Bóné Veronika 2003-ban szerzett szociológus diplomát a Pázmány Péter Katolikus Tudományegyetemen, 2020ban szerzett doktori fokozatot. 2014 és 2021 között a Semmelweis Egyetem laktációs szaktanácsadó képzésének irányítója, 2020 óta a Szoptatást Támogató Nemzeti Bizottság tudományos munkacsoportjának vezetője.

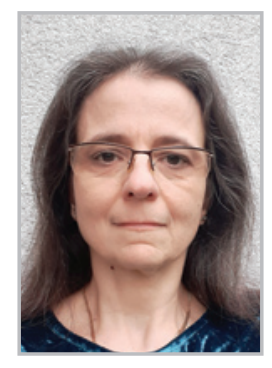

Juhászné Dr. Kun Judit orvos, IBCLC laktációs szaktanácsadó, 2004 óta vesz részt egészségügyi szakemberek szoptatás menedzsmenttel kapcsolatos továbbképzésében, a Semmelweis Egyetem laktációs szaktanácsadó szakirányú továbbképzésének oktatója, az SZTNB Bababarát Kórház Kezdeményezés Munkacsoportjának és Jogi Munkacsoportjának vezetője. 